\title{
DINÂMICAS RECENTES DO SETOR SUCROENERGÉTICO NO BRASIL: COMPETITIVIDADE REGIONAL E EXPANSÃO PARA O BIOMA CERRADO
}

\author{
RICARDO CASTILLO ${ }^{1}$ \\ Universidade Estadual de Campinas
}

\begin{abstract}
Resumo: A partir do início da década de 2000 o setor sucroenergético se difundiu rapidamente em porções selecionadas do território brasileiro, motivado pelo crescimento exponencial do consumo de etanol (etanol hidratado para motores flexfuel no Brasil e etanol anidro para misturar à gasolina em diversos países). Esta expansão tem desencadeado importantes implicações geográficas, econômicas e sociais em diferentes escalas, decorrentes da incessante busca pela competitividade do açúcar e do etanol brasileiros nos mercados internacionais. Com o objetivo de melhor compreender essa situação através de uma perspectiva geográfica, propomos desenvolver quatro pontos: 1) uma análise das características intrínsecas do setor sucroenergético (ou seja, restrições à estocagem da matéria-prima, ciclo vegetativo-econômico da cana-de-açúcar, flexibilidade produtiva das usinas/destilarias, cogeração de energia elétrica, queima da palha da cana-de-açúcar para a colheita manual); 2) uma descrição da dinâmica recente do setor no território brasileiro; 3) uma discussão sobre o conceito de competitividade e sua dimensão geográfica e uma proposta metodológica de identificação das regiões competitivas agroindustriais do setor sucroenergético no Brasil; 4) um esboço da expansão do setor no Cerrado do Centro-Oeste, destacando a emergência de duas regiões produtivas com grande potencial competitivo: as mesorregiões Sul Goiano e Sudoeste do Mato Grosso do Sul.
\end{abstract}

Palavras-chave: Setor Surcroenergético; Bioma Cerrado; Região Competitiva; Território Brasileiro.

\section{RECENT DYNAMICS OF THE BRAZILIAN SUGARCANE SECTOR: REGIONAL COMPETITIVENESS AND THE SECTOR EXPANSION TO THE CERRADO BIOME}

Abstract: Since the beginning of the 21st century, the sugarcane sector has rapidly spread over the Brazilian territory, motivated by the expansion of ethanol fuel consumption under neoliberal regulatory arrangements. This expansion has had strong and far-reaching social, economic and geographical consequences at different scales, from local to global. In order to better understand the

\footnotetext{
${ }^{1}$ Professor doutor do Instituto de Geociências da Universidade Estadual de Campinas. Contato: castillo@ige.unicamp.br.
} 
situation described above from a geographical point of view, we propose to develop four objectives: 1) to analyze and explain the sugarcane sector's intrinsic characteristics (e. g. vegetative-economic cycle of sugarcane, restriction of sugarcane storage, flexible production of sugar mills, bioelectricity production, and the burn of sugar cane straw before manual harvesting); 2) to describe the recent dynamic of the sugarcane sector in the Brazilian territory; 3) to discuss the concept of competitiveness and its geographical dimension, as well as to put forth a methodological proposal for identifying competitive agri-industrial sugarcane regions in Brazil; 4) to briefly discuss the expansion of the sugarcane sector in the Cerrado biome, highlighting two potentially competitive regions: the south of Goiás and the south west of Mato Grosso do Sul.

Keywords: Sugarcane Sector; Cerrado Biome; Competitive Region; Brazilian Territory.

\section{Introdução}

Dois acontecimentos recentes transformaram radicalmente $\mathrm{o}$ setor sucroenergético no Brasil. O primeiro, de natureza regulatória, foi a extinção do Instituto do Açúcar e do Álcool (IAA) ${ }^{2}$ em 1991, decisão política de cunho neoliberal que afastou o Estado do controle direto do setor. O segundo, de natureza tecnológica, foi a produção de veículos equipados com motores capazes de rodar com gasolina e etanol em quaisquer proporções, conhecidos como flexfuel, a partir de 2003. Esses dois eventos, articulados a outros de caráter mais amplo, levaram a uma reestruturação, expansão territorial, internacionalização e oligopolização do setor no país, consolidando a chamada macrorregião canavieira do Centro-Sul do Brasil (SAMPAIO, 2015).

$\mathrm{O}$ aumento exponencial do mercado interno para o etanol (anidro e hidratado) a partir de 2003, potencializado pela dilatação do extrato populacional de renda média com acesso a bens duráveis e, após a crise financeira de 2008, pelas políticas federais de incentivo à aquisição de veículos novos por meio da redução do Imposto sobre Produtos Industrializados - que resultaram num acelerado crescimento das taxas de motorização - deu respaldo à reestruturação do setor sucroenergético no país. A recuperação dos preços do açúcar no mercado mundial entre 2009 e 2014, apesar da curva descendente nos dois últimos anos do período (International Sugar Organization), também contribuiu para amenizar os efeitos da crise mundial no setor.

Nesse novo contexto o modelo de desenvolvimento adotado no país para se tornar autossuficiente em bioenergia e, eventualmente, um grande exportador de etanol e de tecnologias envolvidas em sua produção, foi baseado numa acelerada expansão do monocultivo de cana-de-açúcar, sobretudo em grandes estabelecimentos agrícolas, delineando dois vetores principais de expansão no

\footnotetext{
2 Autarquia da administração pública federal que controlou a produção de açúcar e de álcool no Brasil entre 1933 e 1990. Szmrecsányi e Moreira (1991) e Szmrecsányi e Gonçalves (2009) elaboram uma análise muito apurada sobre o setor no período de vigência do Instituto do Açúcar e do Álcool.
} 
bioma Cerrado a partir do estado de São Paulo: um em direção a Goiás - passando pelo Triângulo Mineiro - e outro em direção a Mato Grosso do Sul, passando pelo norte do Paraná.

Para interpretar a situação brevemente descrita acima propomos estabelecer a relação entre, de um lado, as características intrínsecas ao setor sucroenergético (CASTILLO, 2013), fundamentais para compreender o seu circuito espacial produtivo e identificar a formação de regiões competitivas agroindustriais e, de outro, algumas das condições extrínsecas - aquelas do território brasileiro, particularmente do Cerrado.

Além desta breve introdução e de uma conclusão, este artigo está dividido em quatro partes. Na primeira discutimos as propriedades do setor sucroenergético, antecipando algumas de suas implicações geográficas; em seguida, procedemos a uma avaliação da dinâmica recente do setor no Brasil; a terceira parte é dedicada à descrição de uma proposta teórico-metodológica para a identificação das regiões competitivas agroindustriais do setor sucroenergético; por último, discorremos sobre a expansão do setor no Cerrado brasileiro ${ }^{3}$.

\section{Características intrínsecas ao setor sucroenergético ${ }^{4}$}

A geografia do setor sucroenergético é diretamente influenciada por, pelo menos, cinco características próprias: 1) restrições à estocagem da matéria-prima; 2) ciclo vegetativo-econômico da cana-de-açúcar; 3) flexibilidade produtiva das usinas/destilarias; 4) cogeração de energia elétrica; 5) queima da palha da cana-deaçúcar para a colheita manual.

A lista das características intrínsecas ao setor certamente é maior do que aquela que temos condições de analisar neste momento 5 . De todo modo, as cinco condições mencionadas permitem construir uma base estável para compreender a

\footnotetext{
${ }^{3} \mathrm{O}$ desenvolvimento teórico, os procedimentos metodológicos e as conclusões aqui apresentados resultam de pesquisas financiadas pela Fundação de Amparo à Pesquisa do Estado de São Paulo (FAPESP), pelo Conselho Nacional de Desenvolvimento Científico e Tecnológico (CNPq), pela Coordenação de Aperfeiçoamento de Pessoal de Nível Superior (CAPES) e pelo Comité Français d'Évaluation de la Coopération Universitaire et Scientifique avec Le Brésil (COFECUB) entre 2008 e 2015, com trabalhos de campo nos estados de São Paulo, Mato Grosso do Sul, Mato Grosso e Goiás.

${ }^{4}$ Este item está baseado, parcialmente, em Castillo (2013).

${ }^{5}$ Um bom exemplo daquelas que ficaram de fora desta análise é a pronunciada sensibilidade da canade-açúcar aos ambientes de produção, o que leva a um necessário desenvolvimento endógeno de técnicas agronômicas e à produção de um conhecimento local específico, cujas implicações para o estudo geográfico do setor são muito significativas. Uma excelente análise baseada nessa característica pode ser encontrada em Mesquita (2015).
} 
expansão recente do setor no território brasileiro e algumas de suas implicações locais e regionais.

\section{Restrições ao armazenamento da cana-de-açúcar}

A cana-de-açúcar é uma matéria-prima peculiar porque não pode ser armazenada. Após a colheita (manual ou mecanizada) ela começa a se degradar e deve ser imediatamente processada nas unidades industriais. Algumas importantes implicações decorrem dessa restrição, em várias escalas geográficas: i) a limitação da produção de açúcar, etanol e outros derivados ao período da safra, levando à busca por safras que se estendam por períodos mais longos com o objetivo de utilizar melhor a capacidade produtiva instalada e diminuir a necessidade de armazenamento de açúcar e etanol (BNDES; CGEE, 2008); ii) a impossibilidade de exportar matéria-prima não processada; iii) a necessária proximidade entre as áreas de cultivo e a unidade industrial.

Quanto à terceira implicação, de um ponto de vista puramente geométrico, calcula-se que a usina deve estar situada no centro de um círculo ocupado por canaviais, cujo raio seria de 40 a $50 \mathrm{Km}$ em média (CASTILLO, 2013; CONAB, 2013; SAMPAIO, 2015; PINHEIRO, 2015). No entanto, mais importante do que a distância física é a distância medida em custo e, sobretudo neste caso, em tempo. Por isso, a logística de abastecimento local das usinas é um elemento central da organização produtiva. Outras condições geográficas locais e regionais também exercem um papel de destaque na localização e no desempenho das usinas, tais como a topografia, as restrições ambientais, a estrutura fundiária, o nível de organização de movimentos de resistência, o uso da terra etc. Uma cartografia do alcance potencial de cada usina (em termos de abastecimento de matéria-prima) e de seu perímetro de influência deve levar em conta todas essas variáveis, além da relação entre o rendimento médio regional da cultura (medido em toneladas por hectare) e a capacidade de moagem da usina (medida em toneladas de cana-deaçúcar/ dia).

As consequências mais imediatas dessa característica da cana-de-açúcar é certa rigidez locacional da unidade industrial e um maior "engessamento" do uso do território; ou seja, uma vez que a indústria tenha sido implantada, necessariamente vai haver o cultivo da cana-de-açúcar nas proximidades. Recentemente tais restrições têm estimulado, ainda de forma tímida, o surgimento de unidades industriais capazes de produzir etanol de cana-de-açúcar e de milho, permitindo um melhor aproveitamento da capacidade instalada de moagem ao longo do ano e atenuando os efeitos da proximidade forçada entre indústria e áreas produtoras de matéria-prima. 
É preciso ainda mencionar, com base na impossibilidade de armazenamento por longos períodos e de transporte a longas distâncias da cana-de-açúcar, que as empresas produtoras de açúcar e etanol, teoricamente, têm que se empenhar para assumir o controle de terras próximas através da compra, do arrendamento ou de contratos de fornecimento com produtores externos (terceirização), para garantir o abastecimento de matéria-prima, podendo afetar o preço das terras dentro de seu polígono de atuação, constituído pelas variáveis mencionadas acima (capacidade de moagem da usina, rendimento médio da produção agrícola local, condições naturais e geoeconômicas locais).

\section{Ciclo vegetativo-econômico da cana-de-açúcar}

Apesar de classificada como cultura temporária pelo Instituto Brasileiro de Geografia e Estatística (IBGE), a cana-de-açúcar, na verdade, é uma cultura semiperene. Sua renovação a cada cinco ou seis anos é praticamente obrigatória, uma vez que, depois da quinta rebrota em média a produtividade (rendimento) cai a um nível que acaba tornando mais vantajoso economicamente investir no replantio do que colher a sexta rebrota (EPE, 2012). A manutenção de um rendimento médio elevado numa determinada região ou território depende de um equilíbrio entre áreas em reforma (em período de manejo do solo e preparação para o replantio), áreas de cana-planta (recém-replantadas e prontas para o primeiro corte, quando, em geral, se atinge o maior nível de rendimento), áreas de cana-soca ou segunda folha e áreas de ressoca ou folha de enésima ordem (SANTIAGO; ROSSETO, s.d.), cujo rendimento diminui a cada safra ${ }^{6}$.

Essa condição de semiperenidade da cultura canavieira também contribui para uma maior rigidez do uso do território, dificultando a diversificação produtiva no campo, ainda que seja comum a rotação com culturas de ciclo curto - notadamente leguminosas. Disso decorre, juntamente com as restrições ao armazenamento da cana, uma especialização regional produtiva mais acentuada, tornando a economia dos municípios dedicados à produção de açúcar e etanol muito vulnerável por depender, em grande medida, de um único setor de atividade econômica.

Por esse motivo, o fechamento de uma usina ou a paralisação temporária de suas atividades, por quaisquer motivos, pode comprometer seriamente o Produto Interno

\footnotetext{
${ }^{6}$ Estima-se que a diferença de rendimento entre o primeiro e o segundo corte seja de $10 \%$ a $15 \%$ (informação obtida em entrevista realizada na Companhia Nacional de Abastecimento, em agosto de 2014). A redução de investimentos na reforma dos canaviais, tornando-os envelhecidos, é um dos principais fatores nas eventuais quedas de produtividade do segmento agrícola do setor sucroenergético. De acordo com a EPE (2012, p. 5), "para manter os níveis de produtividade adequados ao ciclo da cultura, a área em reforma na safra 2011/12 deveria [ter sido] de 900 mil ha" no Brasil.
} 
Bruto municipal e a renda de seus habitantes, levando ao colapso, inclusive, o comércio de produtos de consumo final.

\section{Flexibilidade produtiva das unidades agroindustriais}

Outra característica marcante do setor sucroenergético é a possibilidade de direcionar a matéria-prima, dentro de uma mesma unidade produtiva, para fabricar açúcar (diversos tipos), etanol anidro (adicionado à gasolina em diferentes quantidades e insumo para diversas indústrias químicas) ou etanol hidratado (utilizado diretamente como combustível).

Essa condição confere aos agentes detentores das agroindústrias certa flexibilidade que lhes permite adaptar a produção às dinâmicas dos mercados (doméstico e internacional) e das políticas (internas e externas), tais como oscilações do preço do açúcar nas bolsas de mercadorias, decisões de governos nacionais ou regionais sobre adição de etanol anidro à gasolina, subsídios à produção de açúcar de beterraba nos países centrais, decisões da Organização Mundial do Comércio, restrições à importação de etanol (barreiras tarifárias e não tarifárias), congelamento do preço da gasolina no mercado interno, expansão do setor sucroenergético em países concorrentes, dentre outras.

Tal como o açúcar os agentes envolvidos no setor no Brasil, inclusive o Estado, defendem a ideia de que o etanol deveria se tornar uma commodity ${ }^{7}$, em parte para contornar eventuais restrições do produto no mercado internacional, cujo potencial de expansão, sobretudo para o etanol anidro (a ser misturado à gasolina), é considerado grande por seu forte apelo ambiental.

\section{Cogeração de energia elétrica (bioeletricidade)}

Outra singularidade do setor sucroenergético é a cogeração de energia elétrica através da queima do bagaço de cana-de-açúcar. Por ser uma indústria que se situa no campo, existem grandes vantagens em ser autossuficiente em energia elétrica, além da possibilidade de comercializar o excedente. Ao longo da década de 2000, a

\footnotetext{
${ }^{7}$ Compreendemos commodity como um produto primário ou semielaborado, mineral ou agrícola, padronizado mundialmente, cujo preço é cotado nos mercados internacionais em bolsas de mercadorias. Trata-se de uma invenção não apenas econômico-financeira, mas também política, que enfraquece e submete o produtor local - pelo menos quando se trata de commodity agrícola - a uma lógica única ou global e a uma situação sobre a qual não exerce nenhum controle, favorecendo os compradores ou as grandes empresas de comercialização (tradings), à maneira como propõe Appudarai (1986). A lógica das commodities opõe agentes atrelados ao lugar ou região aos agentes que atuam em rede na escala mundial (CASTILLO, 2011).
} 
cana-de-açúcar vem ocupando um papel cada vez mais importante na matriz energética brasileira, tendo chegado a 12,6\% em 2013 (MME).

A substituição do termo "sucroalcooleiro" por "sucroenergético" tem, portanto, uma dupla justificativa: 1) o abastecimento de veículos, seja através do etanol hidratado, seja através do etanol anidro adicionado à gasolina; 2) a produção de bioeletricidade a partir do bagaço da cana.

\section{Necessidade da queima da palha da cana-de-açúcar para a colheita manual}

Os tipos de colheita da cana-de-açúcar, manual ou mecanizada, geram implicações particulares tanto para a questão trabalhista, quanto para a questão ambiental. Ambas estão totalmente relacionadas ao setor. A mecanização da colheita, decorrente da lógica do próprio capital ou das legislações ambientais que restringem a queima da cana, gera impacto direto no nível do emprego temporário sazonal e indireto na redução dos salários e na pressão para o aumento da produtividade de cada trabalhador nas fazendas onde o corte ainda é manual (XAVIER; PITTA; MENDONÇA, 2011). A mecanização da colheita torna-se um meio de contornar ou evitar questões trabalhistas que são particularmente graves no setor; é também uma forma das grandes empresas se alinharem às exigências para obter certificações que atestem práticas de sustentabilidade social e, assim, evitarem restrições ao acesso aos mercados internacionais de açúcar e etanol.

\section{Dinâmica atual do setor sucroenergético no Brasil}

De maneira geral, o setor sucroenergético no Brasil ganha uma nova dinâmica na década de 2000, particularmente a partir de 2003 com a produção de automóveis de passeio e veículos leves de carga híbridos (ver Tabela 1), isto é, que podem utilizar gasolina ou etanol em quaisquer proporções.

\begin{tabular}{|c|c|c|c|}
\hline Ano & $\begin{array}{c}\text { Produção de veículos de } \\
\text { passeio e utilitários leves } \\
\text { flex fuel (gasolina e } \\
\text { etanol) }\end{array}$ & $\begin{array}{c}\text { Total da produção de } \\
\text { veículos de passeio e } \\
\text { utilitários leves }\end{array}$ & $\%$ \\
\hline 2003 & 49.264 & 1.721 .841 & 2,9 \\
\hline 2004 & 332.507 & 2.181 .131 & 15,2 \\
\hline 2005 & 857.899 & 2.377 .453 & 36,1 \\
\hline 2006 & 1.391 .636 & 2.471 .224 & 56,3 \\
\hline 2007 & 1.936 .853 & 2.801 .011 & 69,1 \\
\hline 2008 & 2.250 .924 & 3.009 .034 & 74,8 \\
\hline
\end{tabular}

Tabela 1: Brasil. Produção de veículos flexfuel (gasolina e etanol), 2003-2008.

Fonte: ANFAVEA. 
Do total de licenciamentos de automóveis de passeio e utilitários leves novos no Brasil, os veículos flexfuel (gasolina e etanol) corresponderam a 83,1\% em 2011, 87\% em 2012 e 88,5\% em 2013 (ANFAVEA). A demanda por etanol combustível no país foi suprida pela expansão horizontal da produção de cana-de-açúcar (aumento da área plantada), mais do que pelo crescimento vertical (aumento do rendimento da cultura), como pode ser observado no Gráfico 1 . Podemos notar que a partir do ano de 2003 o ritmo de incorporação de novas áreas pela cultura da canade-açúcar começa a aumentar e o total da área ocupada chega a dobrar entre $2000 \mathrm{e}$ 2012 , enquanto o rendimento médio cresce muito pouco no período, cerca de $10 \%$.

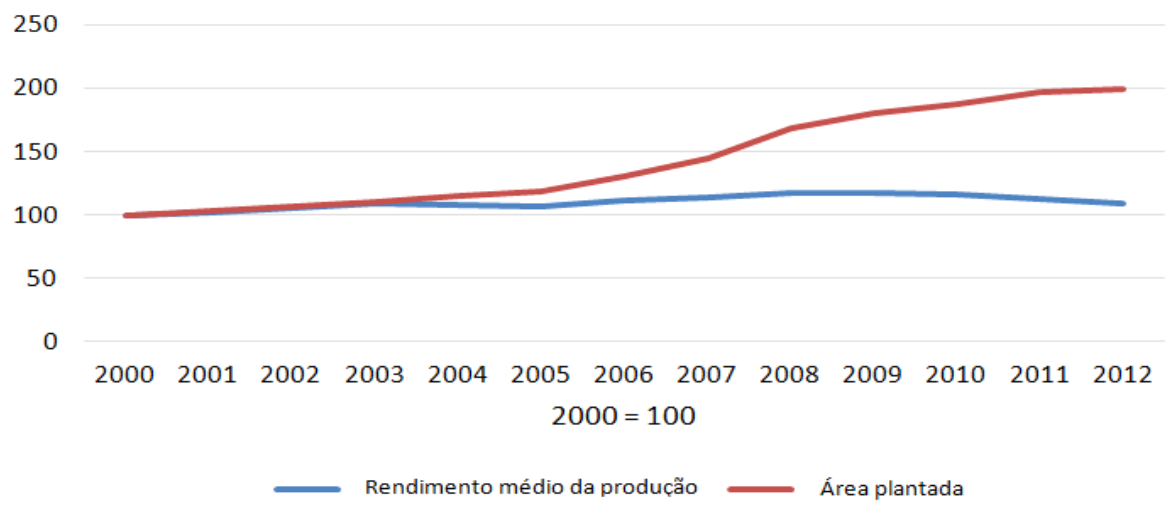

Gráfico 1: Brasil. Área plantada com cana-de-açúcar (ha) e rendimento médio da produção $(\mathrm{Kg} / \mathrm{ha})$ - base $=100,2000-2012$.

Fonte: Produção Agrícola Municipal (IBGE).

A área cultivada com cana-de-açúcar entre 2000 e 2012 se expande preferencialmente no estado de São Paulo e em porções do Cerrado em Minas Gerais, Goiás e Mato Grosso do Sul. Outra manifestação geográfica importante do setor sucroenergético brasileiro nos anos 2000 é a extrema especialização regional produtiva. Dos 3.625 municípios brasileiros que produziram cana-de-açúcar em 2010, em 682 essa cultura respondeu por mais de 50\% de toda a área ocupada pela agricultura (considerando-se a soma de culturas temporárias e permanentes); em 213 desses municípios esse índice oscilou entre 90 e 100\% (PAM-IBGE).

Esta acentuada especialização regional produtiva encontra parte de sua explicação na restrição do armazenamento da cana-de-açúcar e em seu ciclo vegetativo-econômico. As mesmas características influenciam diretamente os contratos de arrendamento de terras para produção de cana-de-açúcar no perímetro de influência de cada unidade industrial, podendo afetar de forma devastadora a pequena produção familiar e provocando aquilo que a Federação dos Trabalhadores da Agricultura do Estado de Goiás (FETAEG) chamou de "esquema para não voltar" (CASTILLO, 2009). A necessidade premente da unidade 
industrial de exercer controle sobre as terras dentro de seu raio de alcance potencial (definido pelas condições geográficas locais), já que o abastecimento de matériaprima é necessariamente local, induz a ações de aquisição, arrendamento e contratos de fornecimento que tornam bastante complexas as relações entre os agentes diretamente envolvidos no setor. A Figura 1 pretende ser um esboço deste intrincado conjunto de relações.
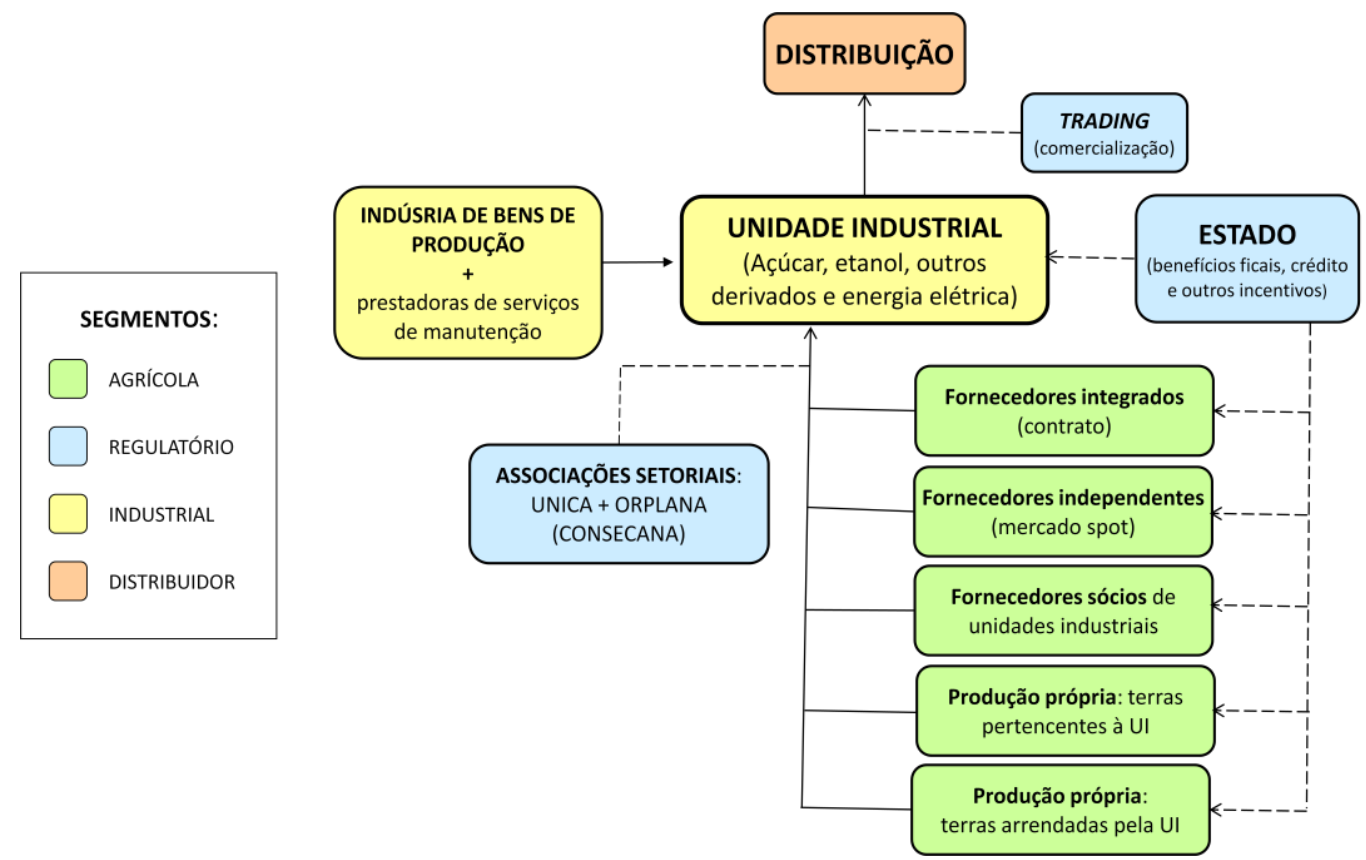

Figura 1: Relações entre os agentes do setor sucroenergético.

Fontes: Trabalhos de campo nos municípios goianos de Rio Verde, Quirinópolis, Inhumas, Anicuns e Goiânia no período de 2008 a 2010 (Auxílio Regular FAPESP), e no Ministério da Agricultura em 2014 (Edital Ciências Humanas do CNPq).

No que compete ao segmento industrial do setor sucroenergético brasileiro, das 414 usinas de açúcar e etanol cadastradas no Ministério da Agricultura, Pecuária e Abastecimento em abril de 2012 (MAPA), 11 produziam somente açúcar (73\% na região Nordeste), 103 produziam somente etanol (82\% na região Centro-Sul ${ }^{8}$ ) e as 300 restantes eram mistas, isto é, produziam açúcar e/ou etanol.

${ }^{8} \mathrm{O}$ setor sucroenergético no Brasil se distribui em duas grandes porções do território que se distinguem por sua história, características naturais, grau de modernização e época da safra: a região Nordeste (equivalente à macrorregião homônima do IBGE) e a região Centro-Sul (equivalente às macrorregiões do IBGE Sudeste, Sul e Centro-Oeste). 
Sobretudo a partir da segunda metade dos anos 2000, grandes empresas de comercialização (trading companies), agroindústrias e empresas tradicionalmente vinculadas à produção de combustíveis fósseis, como a Bunge, ADM, LDC e Shell começaram a investir e se tornaram protagonistas do movimento de oligopolização do setor no país nos últimos anos. Em 2005 os dez maiores grupos detinham 30\% da capacidade de moagem de cana; em 2011 essa participação passa para 43\% (XAVIER; PITTA; MENDONÇA, 2011). Segundo a EPE (2012), a participação das empresas de capital externo na capacidade de moagem do setor passou de $7 \%$ em 2008 para 32\% em 2011. O Quadro 1 relaciona os maiores grupos empresariais que controlam atualmente a produção de açúcar e etanol no país.

\begin{tabular}{|c|c|c|}
\hline GRUPO & Sede & Unidades Industriais \\
\hline Raízen (Cosan + Shell) & SP & 24 \\
\hline Biosev (ldc) & SP & 12 \\
\hline Usaçúcar Santa Terezinha & PR & 9 \\
\hline OdebrechtAgroindustrial & SP & 9 \\
\hline $\begin{array}{c}\text { Bunge(Allianz Global } \\
\text { Investors) }\end{array}$ & SP & 8 \\
\hline TércioWanderley & AL & 7 \\
\hline Guarani / Petrobrás & SP & 7 \\
\hline $\begin{array}{c}\text { InfinityBioenergy } \\
\text { (grupoBertin) }\end{array}$ & SP & 7 \\
\hline Antonio Farias & PE & 5 \\
\hline Aralco & SP & 5 \\
\hline Lincoln Junqueira & SP & 5 \\
\hline Vibo & SP & 5 \\
\hline Carlos Lyra & AL & AL \\
\hline João Lyra & S S & \\
\hline
\end{tabular}

Quadro 1: Brasil. Principais Grupos Empresariais do Setor Sucroenergético, 2013.

Fonte: Anuário da Cana, 2013.

Merece atenção ainda a dinâmica de implantação e fechamento de usinas/destilarias. 137 novas unidades foram adicionadas ao parque industrial brasileiro entre 2005 e 2013, das quais $66 \%$ entre 2005 e 2008, quando então o ritmo de novos investimentos começa a declinar chegando a apenas 2 novas unidades em 2012 e 3 em 2013 (EPE). A crise financeira mundial de 2008 também se expressa no fechamento ou paralisação de usinas no Brasil, que somaram 65 entre 2008 e 2014 (PROCANA). A interrupção da produção e o fechamento definitivo de usinas se devem a problemas jurídicos, financeiros ou a estratégias dos grandes grupos que atuam no setor ${ }^{9}$, provocando severos danos às economias locais (desemprego, estagnação do comércio, queda de arrecadação fiscal etc.).

\footnotetext{
${ }^{9}$ Informação obtida em entrevista no Ministério da Agricultura, Pecuária e Abastecimento em agosto de 2014.
} 


\section{Regiões competitivas agroindustriais do setor sucroenergético: uma proposta teórico-metodológica}

A combinação entre as características intrínsecas ao setor sucroenergético e as condições extrínsecas da formação sócio-espacial brasileira, particularmente do Cerrado - onde o setor se expande de maneira mais acelerada -, é um princípio metodológico fundamental para compreender a organização e o uso do território $\left(\right.$ CASTILLO, 2012) ${ }^{10}$. Uma das expressões desta relação complementar e contraditória entre o setor econômico e o território é a emergência daquilo que vimos chamando de regiões competitivas (GIORDANO, 2005; CASTILLO, 2007; 2009; 2011; 2013) agroindustriais.

Duas proposições teóricas sustentam essa abordagem: 1) a noção de competitividade e sua dimensão geográfica; 2) a coexistência e as articulações entre as diversas formas regionais e as múltiplas escalas territoriais. Com relação à primeira é preciso reconhecer que a literatura sobre o assunto é relativamente recente, porém abundante, tanto em termos acadêmicos - tais como Krugman, 1991; 1994; Dollfus, 1995; Camagni, 2002; 2006; Bristow, 2005; 2010; Giordano, 2005; Droulers, 2009; Ardinat, 2013 - somente para citar alguns autores que tratam da competitividade territorial; quanto em documentos oficiais nacionais e internacionais, como relatórios da UNCTAD (United Nations Conference on Trade and Development) e do Banco Mundial, além de rankings de classificação de países segundo seu nível de competitividade (ARDINAT, 2013).

Sumariamente, podemos dizer que a competitividade é, por um lado, um parâmetro mundializado de desempenho de agentes econômicos e de qualidade e custo dos produtos e, de outro, um discurso que busca justificar a política das empresas e a política dos Estados para assegurar a inserção de alguns produtos em seus respectivos mercados internacionais.

Mas a competitividade também é uma qualidade do espaço geográfico, considerando que as regiões e os territórios podem ser mais ou menos adequados às exigências dos mercados internacionais. A competitividade territorial ou regional resulta da rara combinação entre fatores materiais (naturais e/ou técnicos) e imateriais de produção e de circulação/distribuição de um dado produto ou cadeia produtiva, numa dada fração do espaço geográfico.

\footnotetext{
${ }^{10}$ Compreendemos a organização do território como um conjunto de possibilidades de ação dadas pelas quantidades, qualidades, arranjo e distribuição de objetos naturais e técnicos, mais as normas que regem a propriedade e o acesso a essa base material, num compartimento político do espaço geográfico (GOTTMANN, 1971). Dessas possibilidades aquelas que passam da condição de latência para a condição de existência, isto é, que de fato se realizam, constituem o uso do território (SANTOS; SILVEIRA, 2001). Por sua vez, a regulação do território compreende o jogo de forças (sociais, políticas, econômicas) que se estabelece entre Estado, Mercado e Sociedade Civil Organizada (HIRST; THOMPSON, 1998; ANTAS JR., 2005), facilitando ou dificultando, impedindo ou franqueando determinados tipos de uso a determinados agentes.
} 
A literatura sugere que competitividade deriva de competição (PORTER, 2008), termo com o qual acaba, muitas vezes, se confundindo. Para avançar na discussão e alcançar maior operacionalidade é preciso reconhecer que, embora articuladas, essas duas noções são distintas. Competitividade é um atributo de um agente econômico ou de um compartimento do espaço geográfico (região ou território). Competição, por sua vez, é uma relação estabelecida entre agentes econômicos ou entre regiões ou territórios ${ }^{11}$. Essa necessária distinção permite, por exemplo, identificar uma contradição recorrente nas políticas públicas principalmente a partir dos anos 2000 que, por um lado estimula a competitividade de lugares e territórios e, por outro, suprime a competição entre eles. Esta contradição está impregnada no planejamento setorial e territorial no Brasil.

A segunda proposição, por sua vez, exige um posicionamento claro e objetivo em relação aos conceitos de região e território, já exaustivamente discutidos, principalmente pelos geógrafos. Sem acrescentar nada de novo ao debate partimos do pressuposto de que a atual dinâmica regional brasileira e a própria competitividade regional podem ser expressas na coexistência, na sobreposição, na articulação, nas contradições e no mútuo condicionamento de diversas formas regionais (regiões naturais, regiões tradicionais, regiões de planejamento e regiões produtivas) entre si e delas com os territórios (CASTILLO, 2008), estes compreendidos como recortes ou compartimentos político-jurídico-institucionais do espaço geográfico, tal como propõe Gottmann (1971), em suas diversas escalas de enquadramento das ações do Estado (municipal, estadual e federal).

É preciso ressaltar aqui que territórios e regiões produtivas (SANTOS, 1994; ELIAS, 2007; 2012), competitivas ou não, são muito distintos entre si, em vários aspectos: nas formas de sua emergência e constituição, em sua duração no tempo, nas formas de sua regulação, na precisão de suas delimitações e, sobretudo, naquilo que lhes dá coesão. Considerando que a coesão ou solidariedade organizacional está por trás das regiões produtivas ${ }^{12}$ (SANTOS, 1994), no caso do território será preciso falar de uma solidariedade institucional (CASTILLO et al., 1997), isto é, das forças de coesão político-institucionais que definem um recorte do espaço geográfico com fronteiras reconhecidas e bem demarcadas, um sistema normativo que lhe é exclusivo, certa autonomia tributária, um papel específico no sistema federativo (no caso do Brasil) e, em decorrência, uma capacidade de interferir nas dinâmicas e no nível de competitividade das regiões produtivas.

\footnotetext{
${ }^{11}$ A chamada "guerra fiscal" é uma das características perversas da competição entre os territórios (municípios ou estados) no Brasil, parte de um fenômeno caracterizado por Santos (2002) como guerra dos lugares.

12 "Na definição atual das regiões, longe estamos daquela solidariedade orgânica que era o próprio cerne da definição do fenômeno regional. O que temos hoje são solidariedades organizacionais. As regiões existem porque sobre elas se impõem arranjos organizacionais, criadores de coesão organizacional baseada em racionalidades de origens distantes, mas que se tornam o fundamento da existência e da definição desses subespaços" (SANTOS, 1994, p. 57).
} 
Estas relações entre as formas regionais e os territórios (principalmente municipais) são importantes por diversas razões: 1) porque diversos tipos de região (natural, tradicional, de planejamento) presentes numa dada fração do território nacional podem interferir diretamente no nível de competitividade de uma região produtiva; 2) porque não existe política fiscal de uma região produtiva (eventualmente competitiva), mas sim de cada um dos territórios envolvidos; 3 ) porque se a região competitiva entra em colapso, ela pode simplesmente desaparecer como tal (não sem deixar sequelas), mas os territórios municipais (e suas populações) permanecem e arcam com todas as consequências. É assim porque os princípios de solidariedade geográfica e de regulação de cada tipo de região e dos territórios são completamente distintos.

Estabelecidos esses parâmetros teóricos, podemos dizer que as regiões competitivas agroindustriais do setor sucroenergético podem ser reconhecidas em aglomerados de municípios dedicados à produção de cana-de-açúcar e/ou de seus derivados industriais. De maneira ainda preliminar, os critérios utilizados para identificar as regiões competitivas agroindustriais do setor sucroenergético são:

- o grau de predominância da cultura principal: participação da cana-deaçúcar no total das terras ocupadas pelo conjunto das culturas permanentes e temporárias, nas escalas do município, da microrregião e da mesorregião geográfica do Instituto Brasileiro de Geografia e Estatística (IBGE) ${ }^{13}$;

- o rendimento médio da produção: calculado na escala da microrregião geográfica (toneladas por hectare) e no período mínimo de cinco anos (considerando o ciclo vegetativo-econômico da cana-de-açúcar e os rendimentos decrescentes da produção) e sua comparação com o rendimento médio nas escalas nacional e mundial. É preciso, portanto, considerar a média no espaço e no tempo;

- as condições edafoclimáticas: ambientes de produção mais ou menos adequados à cultura canavieira, conforme classificação proposta pelo Instituto Agronômico de Campinas (MESQUITA, 2015);

- $\quad$ a disponibilidade de cultivares adaptadas às condições naturais locais, sejam elas provenientes de empresas ou de instituições públicas;

- $\quad$ a presença das grandes empresas do agronegócio nas regiões produtivas: agroindústrias; trading companies ${ }^{14}$; landgrabbers ${ }^{15}$; empresas de comercialização

13 A incorporação das áreas ocupadas por pastagens naturais e plantadas poderia aperfeiçoar este
critério, não fossem as dificuldades na obtenção dos dados para todo o território brasileiro na mesma
periodicidade dos dados disponibilizados pela Produção Agrícola Municipal do IBGE.
14 A agroindústria canavieira está excluída dos critérios porque sua presença na região produtiva é
obrigatória, como já observado. No entanto, cabe mencionar que, em algumas situações, a presença
de mais de uma unidade industrial numa mesma região pode levar a disputas por matéria-prima, a
investimentos tecnológicos, a inovações, podendo contribuir para a elevação do grau de
competitividade.
15 A partir, sobretudo, de 2008 empresas especializadas em compra e arrendamento de terras para
produção agrícola, principalmente de grãos, financiadas por grandes fundos de pensão, de
investimentos e soberanos, vêm atuando no território brasileiro e em outros países da América Latina, 
de maquinário agrícola e insumos químicos; prestadoras de serviços de manutenção das usinas e destilarias; empresas de assistência técnica, dentre outros;

- $\quad$ a atuação de associações setoriais e sindicatos patronais: representantes políticos dos interesses dos agentes agroindustriais e dos plantadores de cana-deaçúcar, fundamentais nas reivindicações junto às instituições públicas e na regulação do setor. Dentre os mais importantes, destacam-se a União da Indústria de Cana-de-Açúcar (UNICA), a Organização de Plantadores de Cana da Região Centro-Sul do Brasil (ORPLANA), a Associação dos Produtores de Bioenergia do Mato Grosso do Sul (BIOSUL), o Sindicato da Indústria de Fabricação de Etanol do estado de Goiás (SIFAEG);

- o consumo produtivo agrícola (ELIAS, 2013) e agroindustrial: insumos químicos e biotecnológicos, maquinário, crédito, assistência técnica, informações agrícolas (mercado do açúcar e do etanol) etc.;

- $\quad$ a captação de recursos públicos pelas unidades industriais: aquisição e modernização de usinas e destilarias, replantio, recuperação de solos, desenvolvimento de técnicas agronômicas locais etc.;

- $\quad$ a capacidade instalada de moagem e de controle sobre as terras dentro do raio teórico de alcance da unidade industrial; relação entre cana própria e cana de fornecedores; estratégias de abastecimento de matéria-prima;

- as políticas de benefícios praticadas por estados e municípios: vantagens fiscais, infraestruturas básicas (particularmente em áreas de fronteira agrícola), infraestruturas de transporte;

- o preço da terra e do arrendamento;

- $\quad$ a proximidade com nós logísticos (BRAGA; CASTILLO, 2013): terminais aquaviários, ferroviários e dutoviários.

Evidentemente, alguns indicadores são mais operacionais (dados secundários disponibilizados em bases de acesso livre), enquanto outros somente permitem acesso a titulo oneroso ou dependem de informações primárias, coletadas em trabalhos de campo. Alguns são mais duradouros (condições naturais), enquanto outros estão mais sujeitos a transformações rápidas (tecnologias agronômicas ou industriais). Outros possíveis critérios, como a resistência oferecida por populações locais, são mais difíceis de serem construídos e sistematizados. De uma maneira ou de outra, todos estão vinculados a custo de produção e qualidade do produto, em harmonia com a definição de competitividade discutida anteriormente.

\footnotetext{
África e Ásia, caracterizando uma prática que ficou conhecida como landgrabbing (BORRAS JR. et al., 2011; BORRAS JR. et al., 2012), diferenciando-se da atuação das tradings agrícolas. No setor sucroenergético a empresa RADAR, do grupo COSAN, adota práticas que possivelmente se enquadram na definição de landgrabbing.
} 
É importante destacar, ainda, que a competitividade regional é sempre uma condição provisória, às vezes efêmera, pois se sustenta sobre um conjunto de condições instáveis e não controláveis nas escalas local e regional.

\section{Algumas notas sobre a expansão do setor sucroenergético no Cerrado brasileiro}

De maneira geral, o bioma Cerrado é considerado uma macrorregião natural ${ }^{16}$ que se estende por mais de 2 milhões de quilômetros quadrados em oito estados brasileiros. Há décadas esta porção do território brasileiro vem sendo ocupada pela agricultura moderna, tanto através das políticas territoriais do Estado, quanto pelas estratégias de acumulação de grandes empresas de comercialização e processamento de produtos agrícolas e agroindustriais, não sem inúmeros conflitos e graves contradições.

O Quadro 2 aponta algumas das transformações sociais, econômicas e geográficas pelas quais o Cerrado vem passando em seu processo de modernização agrícola e agroindustrial.

16 Sem prejuízo de suas diferenciações internas, tanto do ponto de vista natural (diferentes fitofisionomias), quanto nas diversas formas de ocupação e reprodução de povos ancestrais e populações tradicionais do(s) Cerrado(s) (RIBEIRO; WALTER, 1998; RIGONATO; ALMEIDA, 2003). 


\begin{tabular}{|c|c|c|}
\hline & CAMPO TRADICIONAL & CAMPO MODERNO \\
\hline AGENTES & $\begin{array}{c}\text { Povos (nações) e } \\
\text { populações tradicionais do } \\
\text { Cerrado }\end{array}$ & $\begin{array}{c}\text { Agricultores } \\
\text { modernizados } \\
\text { ("gaúchos"), tradings } \\
\text { agrícolas, agroindústrias, } \\
\text { comerciantes e prestadores } \\
\text { de serviços especializados, } \\
\text { agentes financeiros, } \\
\text { empresas de compra e } \\
\text { arrendamento de terras, } \\
\text { landgrabbers etc. }\end{array}$ \\
\hline $\begin{array}{l}\text { RELAÇÕES } \\
\text { SOCIAIS }\end{array}$ & $\begin{array}{l}\text { Predomínio de relações } \\
\text { rurais e de uma lógica } \\
\text { endógena e diversificada, } \\
\text { interna ao lugar / região }\end{array}$ & $\begin{array}{l}\text { Predomínio de relações } \\
\text { urbanas e de uma lógica } \\
\text { exógena e padronizada, } \\
\text { externa ao lugar / região }\end{array}$ \\
\hline $\begin{array}{c}\text { RELAÇÕES } \\
\text { COM A } \\
\text { TERRA } \\
\end{array}$ & Ancestral; comunitária & $\begin{array}{l}\text { Propriedade absoluta; terra } \\
\text { como mercadoria }\end{array}$ \\
\hline REGIÃO & $\begin{array}{c}\text { Tradicional: } \\
\text { relações intrínsecas entre } \\
\text { uma população e uma } \\
\text { porção do bioma } \\
\text { (fitofisionomia); grande } \\
\text { diversidade de costumes, } \\
\text { traços culturais, formas de } \\
\text { produção. Maior } \\
\text { autonomia regional }\end{array}$ & $\begin{array}{c}\text { Competitiva: } \\
\text { porções do espaço que } \\
\text { reúnem condições } \\
\text { materiais e } \\
\text { organizacionais capazes } \\
\text { de conferir maior } \\
\text { rentabilidade a } \\
\text { determinados setores } \\
\text { econômicos; inserção } \\
\text { competitiva nos mercados } \\
\text { internacionais; } \\
\text { especialização produtiva } \\
\text { regional; logística etc. } \\
\end{array}$ \\
\hline TENDÊNCIA & $\begin{array}{l}\text { Desparecimento, recuo, } \\
\text { reinvenção, resistência; } \\
\text { proteção institucionalizada } \\
\text { (unidades de conservação, } \\
\text { territórios quilombolas, } \\
\text { reservas indígenas) }\end{array}$ & Expansão \\
\hline
\end{tabular}

Quadro 2: Expansão da fronteira agrícola moderna no bioma Cerrado.

É nesse contexto que ocorre uma acelerada expansão do setor sucroenergético no Cerrado a partir de 2003. Nos estados da macrorregião Centro-Oeste, onde a agricultura em áreas de Cerrado é predominante, a área ocupada pela gramínea passou de 7,6\% a 17,2\% do total do Brasil entre 2000 e 2014, o que significa que a área foi multiplicada por 4,84, ao passo que este índice para o Brasil foi de 2,14. No mesmo período houve uma redução da área plantada em estados historicamente 
importantes para o setor, tais como Pernambuco (-15,1\%), Alagoas $(-2,5 \%)$ e Rio de Janeiro $(-41,8 \%)$ (IBGE). As Figuras 1 e 2, produzidas com base em imagens de satélite, dão uma ideia da dinâmica de expansão da área plantada com cana-deaçúcar entre 2003 e 2012.

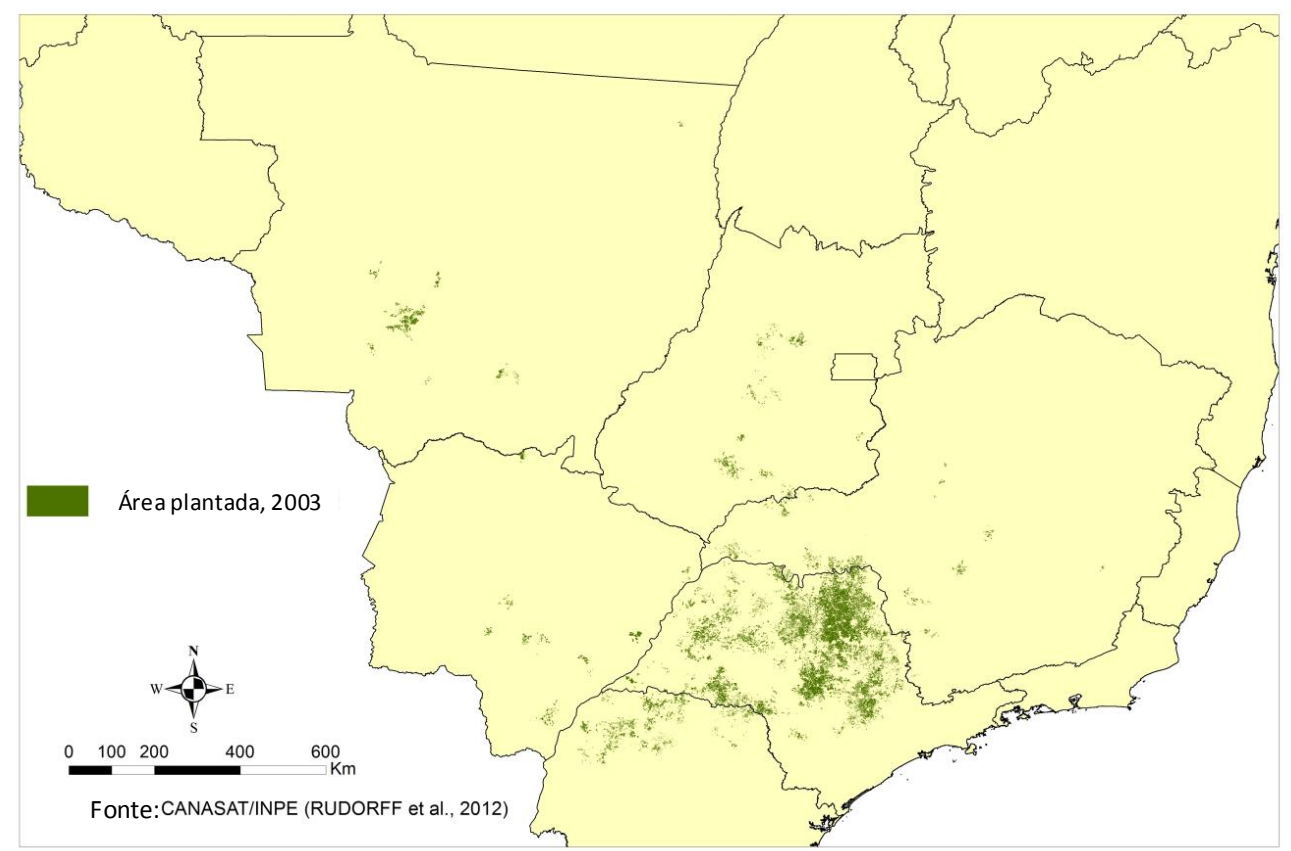

Figura 2: Região Centro-Sul (Brasil). Área plantada de cana-de-açúcar, 2003.

Fonte: Canasat (INPE).

Cartografia:

Júnior

Cesar

Pinheiro. 


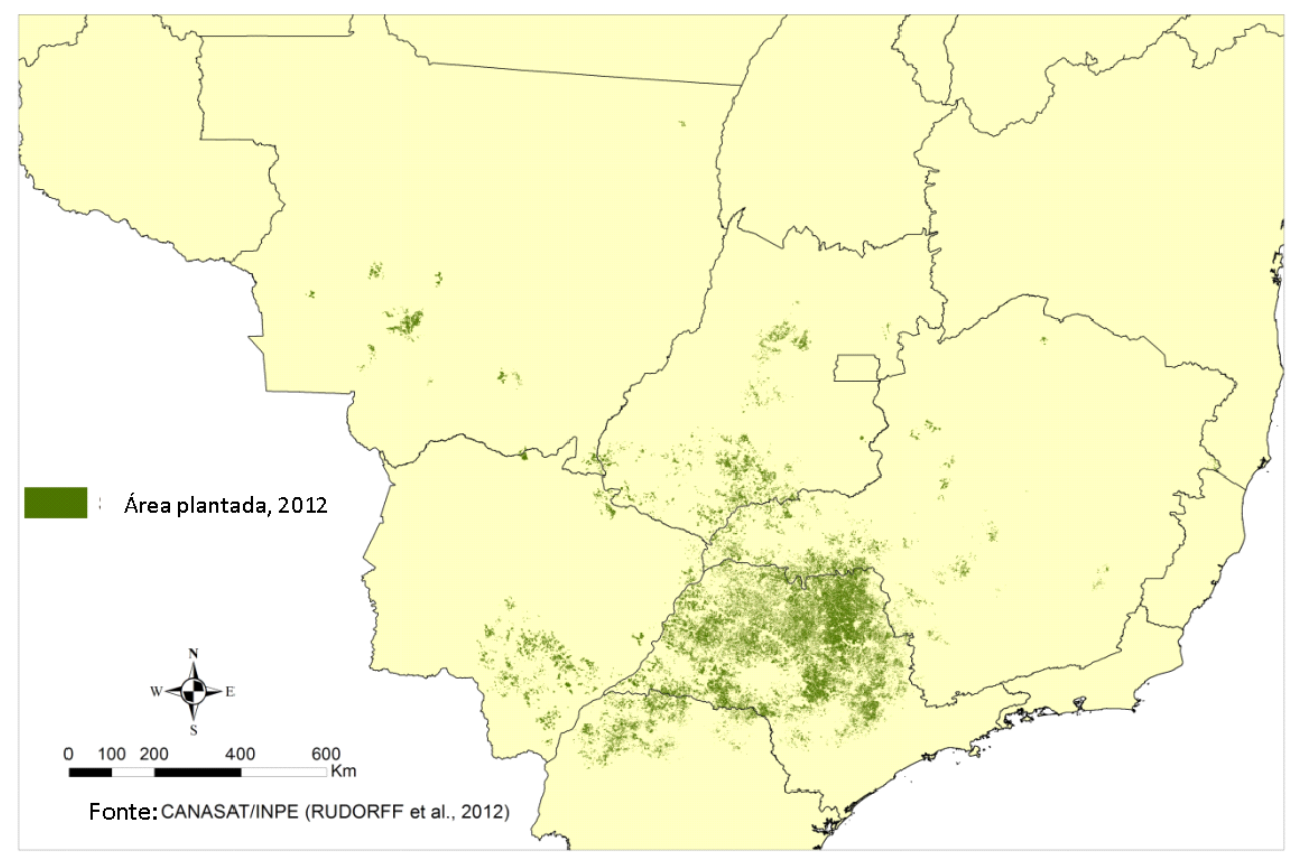

Figura 3: Região Centro-Sul (Brasil). Área plantada de cana-de-açúcar, 2012.

Fonte: Canasat (INPE).

Cartografia: Júnior Cesar Pinheiro.

O aumento da quantidade produzida de cana-de-açúcar entre 2000 e 2014 foi mais acentuado nos estados de Goiás (6,82 vezes) e Mato Grosso do Sul (7,54 vezes) do que a média de toda a macrorregião Centro-Oeste (5,41 vezes) e do Brasil (2,26 vezes). Os Mapas 1 e 2 mostram a quantidade produzida de cana-deaçúcar no Brasil em 2000 e em 2012. 


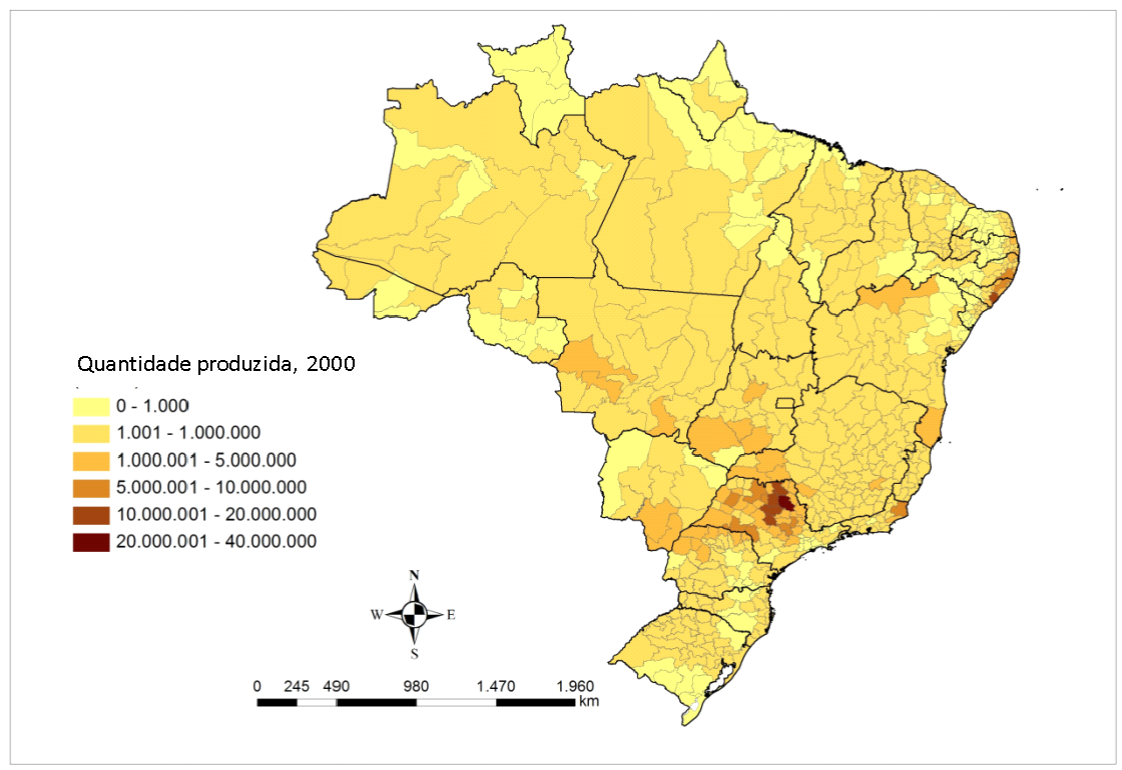

Mapa 1: Brasil. Quantidade produzida de cana-de-açúcar (toneladas), 2000. Fonte: Produção Agrícola Municipal do IBGE.

Cartografia: Júnior Cesar Pinheiro.

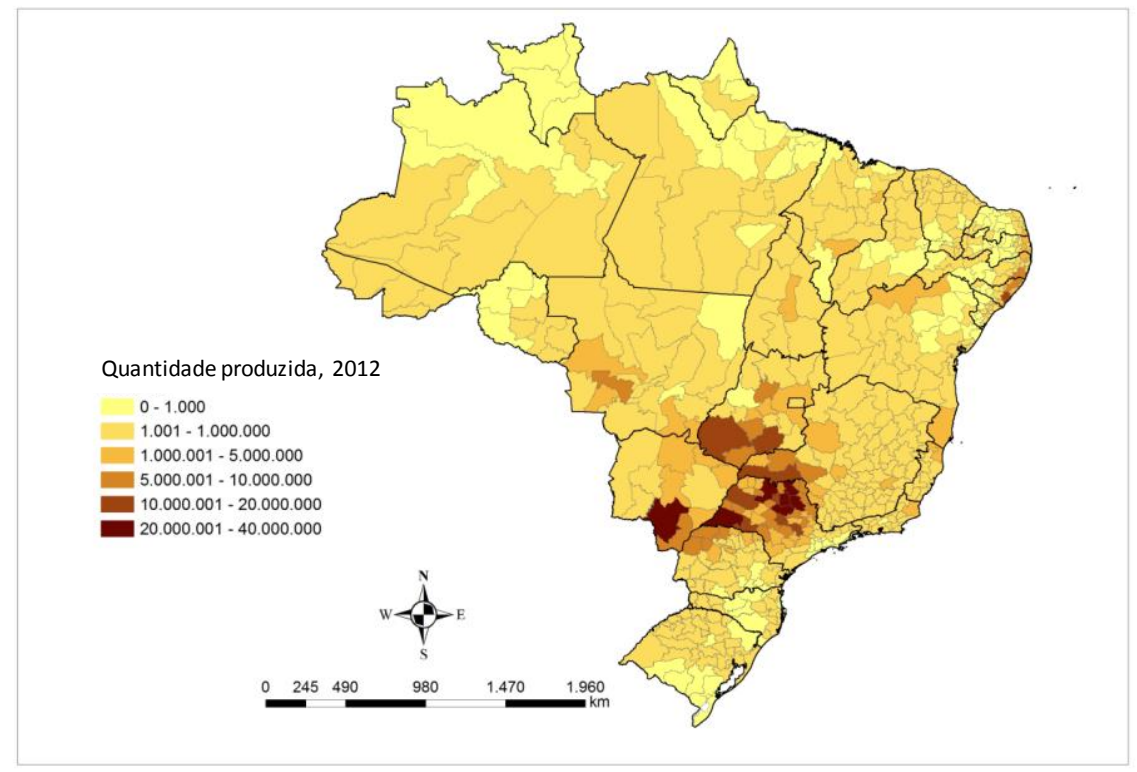

Mapa 2: Brasil. Quantidade produzida de cana-de açúcar (toneladas), 2012. Fonte: Produção Agrícola Municipal do IBGE. Cartografia: Júnior Cesar Pinheiro. 
De maneira ainda preliminar, aplicando alguns dos critérios discutidos anteriormente, é possível vislumbrar pelo menos duas regiões competitivas do setor sucroenergético com potencial para atingir elevados níveis de competitividade no Cerrado do Centro-Oeste, identificadas ainda grosseiramente na escala da mesorregião geográfica do IBGE como Sul Goiano (na qual se destacam os municípios de Quirinópolis, Mineiros, Goiatuba, Itumbiara, Rio Verde, Santa Helena de Goiás, Jataí e Morrinhos) e Sudoeste do Mato Grosso do Sul (com destaque para a microrregião de Dourados e os municípios de Rio Brilhante, Nova Alvorada do Sul, Dourados, Ponta Porã, Maracaju, Caarapó e Juti). O Gráfico 2 mostra a acelerada expansão da área plantada com cana-deaçúcar nessas duas mesorregiões, em comparação com o declínio de duas mesorregiões (Mata Pernambucana e Norte Fluminense) que foram protagonistas do setor em períodos históricos anteriores.

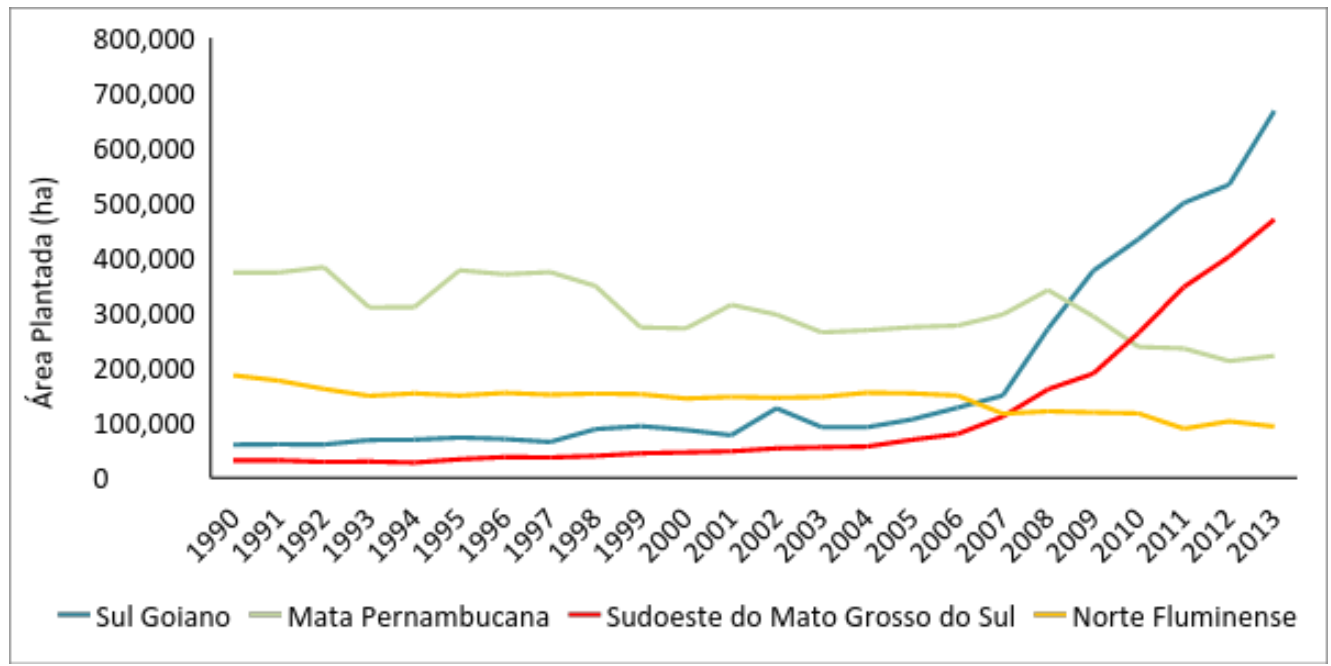

Gráfico 2: Mesorregiões Sul Goiano, Sudoeste do Mato Grosso do Sul, Mata Pernambucana e Norte Fluminense. Ârea plantada com cana-de-açúcar, 1990-2013.

Fonte: Produção Agrícola Municipal (IBGE).

Um estudo sistemático das mesorregiões Sul Goiano e Sudoeste do Mato Grosso do Sul, ambas amplamente beneficiadas por políticas de benefícios fiscais e materiais nos âmbitos municipal e estadual (CAMELINI, 2011), pode revelar as novas tendências de organização e uso do território no bioma Cerrado, ajudar a compreender a pauta de investimentos públicos e privados nessa porção do território brasileiro e decifrar os custos sociais e ambientais envolvidos nesta busca incessante por competitividade. 


\section{Algumas Conclusões}

Não há dúvida de que o setor sucroenergético tem um peso importante na dinamização da economia brasileira ao longo das duas últimas décadas, considerando a geração de empregos, o avanço tecnológico no segmento agrícola (novas cultivares e formas de manejo), a dinamização das indústrias de bens de capital e os serviços produtivos associados (apesar da queda de demanda a partir de 2008), o desenvolvimento tecnológico no segmento industrial (melhor aproveitamento da matéria-prima nas unidades mais modernas), a produção de bioenergia (cogeração de energia elétrica), a expansão da rede dutoviária, dentre outras atividades direta ou indiretamente relacionadas à produção e distribuição de açúcar e etanol. É justo também reconhecer que alguns avanços de caráter ambiental foram conquistados, como a diminuição relativa dos combustíveis fósseis na matriz energética brasileira, a diminuição (pelo menos relativa) do descarte de vinhaça por meio de técnicas de fertirrigação, a redução da queima da palha da cana-de-açúcar devido à maior difusão da mecanização da colheita e a própria legislação ambiental diretamente vinculada ao setor.

No entanto, o modelo de desenvolvimento do setor sucroenergético adotado no Brasil a partir da mudança regulatória decorrente da extinção do IAA em 1991 e da emergência das tecnologias flexfuel para veículos de passeio e utilitários leves em 2003 tem gerado uma série de implicações nas escalas local, regional e nacional.

Dentre as principais características desse modelo, podemos destacar: i) o aumento exponencial da produção de matéria-prima baseado na expansão horizontal da cultura canavieira (ocupação de novas áreas), muito mais do que no crescimento vertical (rendimento médio); ii) a concentração e centralização de capitais no segmento industrial e o aumento da participação de empresas estrangeiras e de outros setores da economia na capacidade de moagem; iii) a consolidação de uma regulação privada no setor, protagonizada por associações setoriais (UNICA, ORPLANA etc.); iv) a drenagem de recursos públicos e a dependência do setor em relação ao Estado para alcançar viabilidade econômica, em alguns casos, e competitividade em outros, através, principalmente, do financiamento da agricultura e da indústria.

Algumas das principais implicações regionais e territoriais constatadas podem ser resumidas nos itens a seguir:

- a especialização regional produtiva no setor sucroenergético tende a ser mais acentuada do que em outros setores agroindustriais, como o de grãos, por exemplo; uma das consequências mais importantes deste fato é que os municípios produtores de cana-de-açúcar e de seus derivados industriais tornam-se mais vulneráveis do ponto de vista social e econômico às oscilações dos mercados e às decisões das grandes empresas; no segmento industrial, o fechamento definitivo de usinas ou a interrupção temporária de seu funcionamento suscita graves problemas para as 
economias locais, de difícil solução; no segmento agrícola, a emergência de regiões competitivas agroindustriais do setor sucroenergético dificulta ainda mais a diversidade produtiva local e regional (redução de custos de oportunidade para culturas diversificadas de abastecimento local e regional) e tende a concentrar em grau superior a terra;

- a prática da fertirrigação, embora possa trazer benefícios futuros, é experimental, uma vez que as quantidades certas para cada tipo de solo ainda estão sendo testadas; o mesmo vale para a quantidade de palha deixada no campo para proteger o solo;

- dadas as restrições ambientais e, principalmente, a necessária proximidade entre plantação e unidade industrial, a expansão da cana-de-açúcar nem sempre pode ocorrer em áreas de pastagens ou de grandes propriedades (onde, teoricamente, causaria menos danos ambientais e sociais), colocando em risco a pequena produção familiar que, dada a condição de semiperenidade com rendimentos decrescentes da cana-de-açúcar e seu ciclo econômico, acaba sujeita às perversidades de longos contratos de arrendamento combinados com a descaracterização das propriedades;

- $\quad$ o tamanho da propriedade, a escala de produção e o rendimento mínimo da cultura, impostos pelo nível de competitividade exigido pelo mercado, conduz à concentração fundiária e à exclusão de pequenos produtores do setor.

Este singular encontro entre as condições intrínsecas ao setor e as condições extrínsecas concernentes à formação sócio-espacial brasileira obriga as grandes empresas a praticarem uma geografia muito refinada para sustentar suas decisões locacionais de fusões e aquisições, de compra e arrendamento de terras, de contratos com fornecedores externos, de logística, de delimitação do alcance potencial da unidade industrial, em razão das características naturais e técnicas locais e regionais.

As pesquisas realizadas até o momento, incluindo a análise documental e trabalhos de campo, permitem inferir que a expansão recente do setor sucroenergético se aproxima da denominada acumulação por espoliação/ despossessão (HARVEY, 2003; BRANDÃO, 2010). Dois processos sustentam esta conclusão: 1) a coexistência articulada entre, de um lado, atividades tecnológica e organizacionalmente modernas tanto no segmento agrícola quanto no industrial e, de outro, formas de trabalho arcaicas e degradantes (superexploração da força de trabalho); 2) a expansão do segmento agrícola baseada num crescimento mais horizontal (através da ocupação de novas áreas) do que vertical (aumento do rendimento da cultura), como já mencionado. 


\section{Bibliografia}

ANTAS JR. R. M. (2005) Território e regulação: espaço geográfico, fonte material e não-formal do direito. São Paulo: Associação Editorial Humanitas Fapesp.

APPADURAI, A. (1986) Introduction: commodities and the politics of value. In: (org.). The Social Life of Things: Commodities in a Cultural Perspective. Cambridge: Cambridge UP. pp. 3-63.

ARDINAT, G. (2013) Géographie de la compétitivité. Paris: PUF.

BNDES; CGEE. (2008) Bioetanol de cana-de-açúcar: energia para o desenvolvimento sustentável. Rio de Janeiro: BNDES.

BORRAS JR., S. M.; HALL, R.; SCOONES, I.; WHITE, B.; WOLFORD, W., (2011) Towards a betterunderstandingof global landgrabbing: an editorial introduction. Journal of Peasant Studies,38, 2. pp. 209-216.

; KAY, C.; GÓMEZ, S.; WILKINSON, J. (2012) Landgrabbing and global capitalist accumulation: keyfeatures in Latin America. Canadian Journal of Development Studies, 33, 4. pp. 402-416.

BRAGA, V.; CASTILLO, R. (2013) Tipologia e topologia de nós logísticos no território brasileiro: uma análise dos terminais ferroviários e das plataformas multimodais. Boletim Campineiro de Geografia, v. 3, nº 2. pp. 235-258

BRANDÃO, C. A. (2010) Acumulação primitiva permanente e desenvolvimento capitalista no Brasil contemporâneo. In: ALMEIDA, A. W. B. et al. Capitalismo globalizado e recursos territoriais: fronteiras da acumulação no Brasil contemporâneo. Rio de Janeiro: Lamparina.

BRISTOW, G. (2005) Everyone's a "winner": problematising the discourse of regional competitiviness. Journal of Economic Geography, 5, 3. pp. 285-304

BRISTOW, G. (2010) Resilient regions: re-'place'ing regional competitiveness. Cambridge Journal of Regions, Economyand Society, 3. pp. 153-167

CAMAGNI, R. (2002) On the concept of territorial competitiveness: sound or misleading? Urban Studies, 39, 13. pp. 2395-2411

. (2006) Compétitivité territoriale: la recherche d'avantages absolus. Reflets et Perspectives de la Vie Économique, XLV, 1. pp. 95-115

CAMELINI, J. H. (2011) Regiões competitivas do etanol e vulnerabilidade territorial no Brasil: o caso emblemático da Quirinópolis, GO. Dissertação (Mestrado em Geografia) - Instituto de Geociências da Universidade Estadual de Campinas. Campinas.

CASTILLO, R.; TOLEDO JR., R.; ANDRADE, J. (1997) Três dimensões da solidariedade em geografia: autonomia político-territorial e tributação. Experimental, 3. pp. 69-99.

CASTILLO, R. (2007) Agronegócio e logística em áreas do Cerrado: expressão da agricultura científica globalizada. Revista da ANPEGE, 3. pp. 33-43. 
(2008) Região competitiva e logística: expressões geográficas da produção e da circulação no período histórico atual. Anais. IV Seminário Internacional sobre Desenvolvimento Regional. Santa Cruz do Sul: Unisc.

. (2009) Região competitiva e circuito espacial produtivo: a expansão do setor sucroalcooleiro no Brasil. Anais. VIII Encontro Nacional da ANPEGE (Associação Nacional de Pós-Graduação e Pesquisa em Geografia). Curitiba.

. (2011) Agricultura globalizada e logística nos cerrados brasileiros. In: SILVEIRA, M. R. (org.). Circulação, transportes e logística: diferentes perspectivas. São Paulo: Outras Expressões.

. (2012) Redes geográficas e território brasileiro. Relatório de Atividades apresentado ao Instituto de Geociências da Universidade Estadual de Campinas, referente à Licença Especial. Inédito. Campinas, 216 p.

(2013) A expansão do setor sucroenergético no Brasil. In: BERNARDES, J. A.; SILVA, C. A.; ARRUZZO, R. C. (org.). Espaço e energia: mudanças no paradigma sucroenergético. Rio de Janeiro: Lamparina. pp. 75-84 COMPANHIA NACIONAL DE ABASTECIMENTO (2013). Perfil do setor do açúcar e do álcool no Brasil /responsáveis técnicos Ângelo Bressan Filho e Roberto Alves de Andrade. v. 5 - Safra 2011/2012 - Brasília: Conab. 86 p.

DOLLFUS, O. (1995) Mondialisation, compétitivité, territoires et marchés mondiaux. L'Espace Géographique, v. 24, nº 3. pp. 270-280.

DROULERS, M. (2009) Le défi des biocarburants au Brésil. L'Information Géographique, 73, 1. pp. 82-97.

ELIAS, D. (2007) O meio técnico-científico-informacional e a reorganização do espaço agrário nacional. In: MARAFON, J. G. et al. (org.). Abordagens teóricometodológicas em geografia agrária. Rio de Janeiro: EdUERJ.

. (2012) Les territoires de l'agrobusiness au Brésil. Confins, 15.

(2013) Regiões produtivas do agronegócio: notas teóricas e metodológicas. In: BERNARDES, J.; SILVA, C. A.; ARRUZZO, R. C. Espaço e energia: mudanças no paradigma sucroenergético. Rio de Janeiro: Lamparina. pp. 201-220.

EPE - Empresa de Pesquisa Energética do Governo Federal (2012) Análise de conjuntura dos biocombustíveis: janeiro 2011 - dezembro 2011. Brasília: EPE. GIORDANO, S. R. (2005) Competividade regional e globalização: o agronegócio da soja brasileira nos anos 90. Campinas : Akademica.

GOTTMANN, J. (1971) The evolution of the concept of territory. Social Science Information, 14, 3/4. pp. 29-47.

HARVEY, D. (2003) The new imperialism. New York: Oxford UniversityPress.

KRUGMAN, P. (1991) Geography and trade. Louvain/ Cambridge: Leuven UniversityPress/ MIT Press.

. (1994) Competitiviness: a dangerous obsession. Foreign Affairs, 2, 73.

MESQUITA, F. C. (2015) Evolução da agricultura e transformações da paisagem no Cerrado goiano: a dimensão endógena da expansão da agroindústria canavieira. 
Tese (Doutorado em Geografia) - Instituto de Geociências da Universidade Estadual de Campinas. Campinas.

PINHEIRO, J. C. (2015) Análise da dinâmica das áreas ocupadas pela cultura canavieira no Brasil entre 1990 e 2013: uma contribuição ao estudo do circuito espacial produtivo do setor sucroenergético. 167 f. Dissertação (Mestrado em Geografia) - Instituto de Geociências, Universidade Estadual de Campinas. Campinas.

PORTER, M. (2008) On Competition. New Haven: Harvard Business Review. RIBEIRO, J. F.; WALTER, B. M. T. (1998) Fitofisionomias do Bioma Cerrado. In: SANO, S. M. et al. Cerrado: ambiente e flora. Planaltina, DF: Embrapa-CPAC. RIGONATO, V. D.; ALMEIDA, M. G. (2003) As fitofisionomias e a inter-relação das populações tradicionais com o Bioma Cerrado. Relatório de Pesquisa Cultura, conhecimento popular e uso das espécies pelos pequenos agricultores do Cerrado. Goiânia: POCPG/CNPq.

SAMPAIO, M. A. P. (2015) $360^{\circ}$ : o périplo do açúcar em direção à Macrorregião Canavieira do Centro-Sul do Brasil. 799 f. Tese (Doutorado em Geografia Humana) - Universidade de São Paulo. São Paulo.

SANTIAGO, A. D.; ROSSETO, R. (s.d.) Rotação e reforma da cana-de-açúcar. Agência Embrapa de Informação Tecnológica. Disponível em: <http://www.agencia.cnptia.embrapa.br/gestor/cana-

deacucar/arvore/CONTAG01_75_22122006154841.html>. Acessado em: jan. 2015.

SANTOS, M. (1994) Técnica, espaço, tempo: globalização e meio técnicocientífico-informacional. São Paulo: Hucitec.

. (2002) O país distorcido: o Brasil, a globalização e a cidadania. São Paulo: Publifolha

; SILVEIRA, M. L. (2001) O Brasil: território e sociedade no início do século XXI. Rio de Janeiro: Record.

SZMRECSÁNYI, T.; MOREIRA, E. P. (1991) O desenvolvimento da agroindústria canavieira do Brasil desde a Segunda Guerra Mundial. Estudos Avançados 11(5). pp. 57-79

; GONÇALVES, D. B. (2009) Efeitos socioeconômicos e ambientais da expansão da lavoura canavieira no Brasil. Congresso LASA (Associação de Estudos Latino-americanos). Rio de Janeiro.

HIRST, P.; THOMPSON, G. (1998) Globalização em questão. Petrópolis: Vozes. XAVIER, C. V.; PITTA, F. T.; MENDONÇA, M. L. (2011) Monopólio da produção de etanol no Brasil: a fusão Cosan-Shell. São Paulo: Outras Expressões. 